\title{
Invisible Happiness in Dogen
}

\author{
T. J. Sellari \\ Department of English, National Chengchi University, Taiwan \\ Email: tsellari@gmail.com
}

How to cite this paper: Sellari, T.J. (2017) Invisible Happiness in Dogen. Open Journal of Social Sciences, 5, 261-273.

https://doi.org/10.4236/jss.2017.510023

Received: September 27, 2017

Accepted: October 28, 2017

Published: October 31, 2017

Copyright $\odot 2017$ by author and Scientific Research Publishing Inc. This work is licensed under the Creative Commons Attribution International License (CC BY 4.0).

http://creativecommons.org/licenses/by/4.0/

\begin{abstract}
Buddhism is frequently referenced as one of the possible paths for the modern quest for happiness. An examination of Buddhist literature, however, shows that the attempt to trace such a route is somewhat misguided, for Buddhism addresses primarily the avoidance of suffering rather than the pursuit of happiness. In fact, a concern with happiness is often characterized in Buddhist texts as a pitfall to be avoided rather than as a path to be followed. This paper examines the near-invisibility of happiness in the writings of Dogen Zenji, a seminal Zen teacher and writer, and demonstrates how the negligible place of happiness in Dogen's writings corresponds to its conceptual space in Buddhism generally, thus showing that the elimination of suffering, which is the goal of Buddhism, should not be reduced to happiness. As a link between modern writers on Buddhism and the earliest Buddhist texts, Dogen presents an instructive case to illustrate how the theme of happiness holds a position in Buddhist thought even when it is not explicitly mentioned, but that place is far from central to Buddhism's concerns. Nevertheless, Dogen's writings furnish splendid examples of what we might call "literary happiness"-a kind of happiness enacted rather than discussed. The identification of such happiness shows how in Buddhism happiness is more incidental than teleological, and suggests that the application of Buddhist concepts to the quest for happiness twists those concepts in a direction inimical to Buddhist practice.
\end{abstract}

\section{Keywords}

Happiness, Buddhism, Zen, Dogen, Literary Style

\section{Buddhism and the Pursuit of Happiness}

\subsection{Happiness and Buddhism in the Popular Imagination}

In his recent analysis of the large-scale encouragement toward the pursuit of happiness, The Happiness Industry. How Government and Big Business Sold Us Well-Being, William Davies begins with an account of the Buddhist monk Mat- 
thieu Ricard, who is the French translator for the Dalai Lama and a noted speaker at TED, and has been called the happiest man in the world ([1], pp. 1-3). Ricard appeared at the World Economic Forum in Davos in 2014 to teach meditation and relaxation techniques to the attendees, who were provided with gadgets to measure their physical and mental well-being on their smartphones. Similarly, books linking advances in neuroscience with Buddhism may extol the salubrious effects of Buddhist meditation on health as well as on levels of happiness (which themselves lead to better health outcomes) ([2], p. 29). When the goal shifts from the alleviation of suffering to the pursuit of happiness and health, Buddhism is treated as a cultural resource to be mined for other ends. Watson, for example, emphasizes that "Buddhism is a rich resource [...] to foster wellbeing and help repair dis-ease [sic]" ([2], p. 30). Addressing such exploitative uses, Davies points out that happiness has become the latest in a series of desirable commodities. When a means to gain those commodities-such as Buddhism, in this case-is applied as part of a philosophy of productivity, it is reduced to another form of competitive acquisitiveness that is encouraged by the prevailing ideologies of our society ([1], pp. 10-11). In short, when it comes to happiness, public values are warping the very ideas that are supposed to be informing their pursuit.

How such skewing occurs is not puzzling. Davies points out the awkward ideological space that happiness occupies. Describing how today's "psychological management" works, he writes:

Neurological, physiological and behavioural monitoring devices are clamped together with meditation practices and pop existentialism. The philosophical deficit in the science of happiness is dealt with by importing ideas from Buddhism and new age religions. Somewhere in between the quantitative science and spiritualism sits happiness. ([1], p. 38)

In other words, the modern pursuit of happiness does not stem from Buddhism, but merely borrows from it a patina of philosophical justification. Thus, this pursuit of happiness is not informed by Buddhism in any meaningful sense, and it is in no way a development of Buddhist thought.

The danger of mixing disparate philosophies is anticipated by Bhikkhu Bodhi, a noted translator and author of Buddhist texts, when he warns that such eclecticism "compromises the very traditions it draws upon" ([3], p. 2), and that different spiritual traditions "are not mutually compatible" ([3], p. 3), for "major differences in perspective [...] point to very different experiences constituting the supreme goal and the path that must be trodden to reach that goal" ([3], p. 3). As Bhikkhu Bodhi notes, genuine spiritual paths are incompatible when pursued to any depth; yet the incompatibility between a genuine spiritual path such as Buddhism on one hand and the mixture of optimism, brain science, and marketing that is the current pursuit of happiness described by Davies on the other may not be so easy to identify, for the appropriation of Buddhist ideas by the happiness movement is camouflaged both by the shallowness of the appropriation and by the general tendency to emphasize the happy personalities of Budd- 
hist masters and the cheerful expression of Buddhist ideals. The next two sections of this paper aim to uncover such incompatibility by examining the place of happiness in modern Buddhist writings and tracing it back to its roots in the earliest Buddhist scriptures, the Pali canon.

\subsection{Modern Buddhist Writings on the Pursuit of Happiness}

The distance between the modern pursuit of happiness and the Buddhist view of happiness becomes apparent from a reading of modern Buddhist writings on the topic. Perhaps no modern Buddhist author has delineated the place of happiness in Buddhism more clearly than Ajahn Chah, a Thai Buddhist master of the forest tradition. "The Middle Way," he writes, "is all about letting go of happiness and unhappiness, and the right practice is the practice of the middle" ([4], p. 204). Happiness is as carefully to be avoided as unhappiness. Ajahn Chah calls happiness "the loose path" and characterizes it as "indulgence in sense pleasures" ([4], p. 244). Craving for happiness gives rise to suffering when that craving is not satisfied ([4], p. 204), and, since impermanence is one of the three characteristics of existence in Buddhist thought $([5]$, p. 6), we can be certain that whatever satisfaction that is found will be only temporary.

The key point according to Buddhism is to avoid clinging to happiness. Describing the Buddha, Ajahn Chah notes that

And there was happiness, too, but he knew that happiness, if it's not known, is like a poison. He didn't hold it to be himself. Happiness was there through knowledge, but he didn't cling to it or carry it around in his mind. Thus we say he separated happiness and unhappiness from his mind. ([4], p. 301)

Thus, it is a kind of distance from happiness that should be cultivated: "The natural state of the mind is neither happiness nor unhappiness [...] Happiness is there, but it's 'outside' the mind, not buried within it," ([4], p. 300). Happiness is something to be known, but we must understand ourselves as being separate from it:

[...] the mind must know happiness and know unhappiness. When sitting in samādhi, for example, and peace fills the mind, then happiness arises but doesn't reach us; unhappiness arises but doesn't reach us. This is what separating the feeling from the mind means. ([4], p. 300)

It should be noted that even writers who aim to propagate Buddhism conflate freedom from suffering and happiness. Tien Cong Tran, for example, describes Nirvana (Pali: Nibbāna), the cessation of suffering, as "happiness" ([6], p. 109), and claims that, according to the Buddha, "What brings happiness constitutes the essence of man" ([6], p. 109). Similarly, describing the enlightenment of the Buddha, Bien writes that the Buddha "left sorrow behind and entered the happiness of nirvana" ([7], p. 48). Such a description is misleading, for it ignores the proper place of happiness within Buddhist thought and thus mars the clarity and consistency of the Buddhist view of life. 
What, then, is happiness in Buddhism? Ajahn Chah defines it as "a pleasant feeling in the mind" [4], p. 300), thus assigning to it the same general status as unhappiness. Both happiness and unhappiness are subsumed under the term "feeling":

Feeling is the characteristic of happiness of unhappiness, liking or disliking. When the mind indulges in these things, we say that it clings to or takes that happiness or unhappiness to be worthy of holding. That clinging is an action of mind, and that happiness or unhappiness is a feeling. ([4], p. 300)

Rather than pursuing either one of these feelings, however, the observant Buddhist separates them from the mind. The generic equivalence of happiness and unhappiness within the Buddhist scheme is clear: "The Buddha knew that because both happiness and unhappiness are unsatisfactory, they have the same value" ([4], p. 301). Ajahn Chah consistently downplays the significance of happiness: "When a mental impression arises that we like, we know it as such; we don't hold it to be anything substantial. It's just happiness" ([4], p. 302). In the end, he exorts us to relinquish any identification of ourselves and happiness: "We know the painful or comfortable states but we don't identify with them [...] You must live like this, that is, without happiness and without unhappiness. You stay only with the knowing," [4], p. 302). As Ajahn Chah describes it, Buddhist practice is an effort to live in "peace beyond both comfort and pain" ([4], p. 302).

Indeed, the pursuit of happiness is actually a distraction from the Buddhist practices that aim at ending suffering, the Dharma or "way" of the Buddha. Ajahn Chah explains that it is ignorance of this way that causes obsession with happiness: "Why are we under the sway of happiness and suffering, gladness and dejection? Because we don't know Dharma, we do not see Dharma" ([8], p. 159). The tendency to identify oneself as inseparable from whatever happiness (or unhappiness) one experiences shows the mutually-reinforcing nature of preoccupation with happiness and preoccupation with self. Buddhism denies any unchanging quality to the self, so such preoccupations can only stem from, and in turn cause, misunderstanding and further suffering. Describing such misunderstanding, Ajahn Chah explains the interconnection between attachment to a feeling like happiness and attachment to one's sense of self:

We believe happiness to be ourselves, we see ourselves as happy. We believe suffering to be ourselves and see ourselves as unhappy. We can't pull the mind out of this view, which means not seeing nature. There isn't any self involved, but we are always thinking in terms of self. Thus it seems that happiness happens to us, suffering happens to us, elation happens to us, depression happens to us. The chain of self is constructed, and with this solid feeling that there is a self, everything seems to be happening to us. ([8], pp. 166-167)

That is, the problem lies in our confusing an emotion like happiness with an essential self: "we identify with our emotions and are thus tortured by our wrong 
understanding" ([9], p. 23). Thus, the pursuit of happiness cannot constitute a path to self-improvement, at least as it is conceived within Buddhism.

Ajahn Chah nevertheless advocates understanding both happiness and unhappiness. The key to such understanding lies in the Buddhist insistence on cause and effect:

We who study should learn about cause and effect. happiness comes from such and such causes, suffering comes from such and such causes. We come to know that there is always cause and result in actions. But the Dharma realized by the Buddha is pacification, that which is above cause and result, beyond happiness and suffering, beyond birth and death. ([8], p. 178)

In Buddhist thought, such pacification is the recommended alternative to striving to gain happiness or avoid unhappiness, both of which are distractions from practice stemming from and reinforcing a basic conceptual error. Note that in every one of these quotations, Ajahn Chah pairs happiness with unhappiness, seeing them both as distractions, though in opposite directions, from the Middle Way that is Buddhist practice.

In taking Ajahn Chah as an explicator of the proper position of happiness in Buddhist thought, this paper does not contradict the apparent focus of other leading exponents of Buddhism who do focus on happiness in their teaching. Perhaps the most well-known example of such a figure is the Dalai Lama, whose teachings on happiness are recounted in The Art of Happiness: A Handbook for Living. There, the Dalai Lama explains the same issue of cause and effect that is essential to an understanding of happiness: "If you desire happiness, you should seek the causes that give rise to it, and if you don't desire suffering, then what you should do is to ensure that the causes and conditions that would give rise to it no longer arise" ([10], p. 39). Such a teaching is entirely consistent with Ajahn Chah's comments on cause and effect quoted above.

\subsection{Buddhist Teachers: Personalities, Skillful Means, and Buddhist Thought}

It may seem paradoxical that a teacher such as Ajahn Chah, who warned so clearly of the inadvisability of grasping happiness, is remembered for his joyful, playful attitude and sense of humor, which have been long noted by his disciples and lay followers. One of the translators of his works, Paul Breiter, recalls that, "Those who met him were invariably struck by the joyousness which sprang from the inner freedom he had realized" ([11], p. xiv). While he could be harsh and demanding, and did not hesitate to recount the personal experiences of his monks as means of instruction, Breiter notes that, "He always told the stories in a gentle and funny way, everyone would have a good laugh, and he would make his point" ([11], p. 25). By all accounts, Ajahn Chah seems to have been the source of a great deal of happiness as well as instruction.

Such accounts are far from rare. The history of Buddhism is replete with accounts of teachers who combine scrupulous obedience and severity with kindness and humor, strict practice and a happy demeanor. There are two reasons 
for such accounts. The first is the obvious one that has already been mentioned above: the actual "inner freedom" and "joyousness" that result from the realization of truth. The second is the propensity for disciples and students to see their teachers in a positive light, and to depict them accordingly. Thus, an account of Harada-roshi, a Soto Zen teacher renowned for his serious attitude toward Zen practice, can contain the following emollient: "For all his sternness Harada-roshi had his gentle side, and though he never married but remained a monk in the true sense of the word, he loved to romp with children and was exceedingly fond of animals, particularly dogs" ([12], p. 305). The essence of such accounts as means of spreading Buddhist thought is expressed by the later Mahayana concept of upāya, or skillful means, which "justify a range of pragmatic propositions which represent a healthy way of viewing the world, regardless of what the world is actually like" ([13], p. 180). In other words, the portrayal of a teacher as happy will likely help that teacher's message to spread all the more readily, regardless of the relevance of such a portrayal to the content of the teaching itself. I do not in the least want to imply that such accounts are fabricated or misleading, but rather point out that they are more closely connected to perceptions of the overall advisability or attractiveness of the teaching, rather than to the truth of its content. On the other hand, it might also be argued that the person of the teacher is the most truthful expression of his or her teaching. In any case, in order to allow us to identify Buddhist ideas on happiness in the writings of Dogen, it remains to trace modern accounts like those of Ajahn Chah's back to their sources in the Pali Canon, the task to which the next section turns.

\subsection{Buddhist Scriptures on Happiness}

The key to locating Dogen's comments on happiness lies in the lists of the five aggregates (Sanskrit: skandha; Pali: khandha) in the Buddhist scriptures of the Pali canon. It is attachment to these five aggregates-body or form, feeling, perception, intention or volition (mental formations), and consciousness-that causes suffering ([5], p. 5). These five aggregates are listed, for example, in the Book with Verses (Sagāthāvagga), and are referred to in innumerable places in the Pali Canon ([14], p. 206). (As we will see, this list is repeated many times by Dogen.) Happiness is most immediately connected to the aggregate of feeling, which may be of three types: pleasant, unpleasant, or neutral. In the part of the Pali Canon known as the Book of Causation (Nidannavagga), the Buddha approves the following explication of feeling by the Venerable Sāriputta: "Friends, there are these three feelings. What three? Pleasant feeling, painful feeling, neither-painful-nor-pleasant feeling. These three feelings, friends, are impermanent; whatever is impermanent is suffering" ([14], p. 569).

As the source of emotions such as happiness, the five aggregates are the most pertinent to Dogen's conception of happiness. The Pali Canon mentions happiness in other contexts, too, though. For example, in the sutra titled "A God Consults the Buddha" (Sakkapanha Sutra), the Buddha identifies two kinds of happiness, one to be pursued, and one to be avoided: 
This is how I understood happiness. When I observed that in the pursuit of such happiness, unwholesome factors increased and wholesome factors decreased, then that happiness was to be avoided. And when I observed that in the pursuit of such happiness unwholesome factors decreased and wholsesome ones increased, then that happiness was to be sought after. Now, of such happiness as is accompanied by thinking and pondering, and of that which is not so accompanied, the latter is the more excellent. ([15], p. 329)

The kinds of happiness to be pursued are likely those that have a positive role in the achievement of a progression of states of consciousness known as the jhānas. In their explanation of $A$ Comprehensive Manual of Abhidhamma by Ācariya Anuruddha, U Rewata Dhamma and Bhikkhu Bodhi explain the type of happiness (Pali: sukha) that accompanies the jhānas.

This jhāna factor is pleasant mental feeling. It is identical with somanassa, joy, and not with the sukha of pleasant bodily feeling that accompanies wholesome-resultant body-consciousness. This sukha, also rendered as bliss, is born of detachment from sensual pleasures; it is therefore explained as nirāmisasukha, unworldly or spiritual happiness. It counters the hindrance of restlessness and worry. ([16], p. 57)

This type of happiness is conducive to Buddhist practice, and therefore must be one of the types of happiness to be pursued-not as an end in itself, but as a useful attribute of practice. Such happiness results from tranquility ([17], p. 72), and is part of a chain of causes and effects listed in the Nidānasamyutta; this kind of happiness itself causes concentration ([14], pp. 553-556). Even the most positive references to happiness, then, avoid treating it as a pursuit in itself. Its appearance is, in a sense, incidental to Buddhist practice, but is not its goal.

\section{Dogen and Happiness}

\subsection{Finding Happiness in Dogen}

If we treat Buddhist thought not in terms of its variety of forms and expressions, but in terms of the core concepts shared across the spectrum of Buddhist beliefs and practices, it is not difficult to see Dogen as a kind of middle ground between the Pali Canon and modern authors, since his works have somewhat canonical status within Zen, which is, perhaps, the most familar form of Mahayana Buddhism in the West. His works have been described as "fascinating" and extraordinarily rich" because of Dogen's "verbal and linguistic finesse" ([18], p. 13). In his preface to Dogen's Treasury of the True Dharma Eye (Shobogenzo), translator and editor Kazuaki Tanahashi calls Dogen "one of the greatest writers in Zen Buddhism throughout time and space" and "one of the most extensive elucidators of Buddhist scriptures" ([19], p. xiv.) It is not surprising, then, to find the terms and concepts of Buddhist scriptures appearing throughout Dogen's work, though he directly cites later thinkers such as Nagarjuna, who is considered a source for Mahayana Buddhism, which develops away from the reliance on the 
Pali Canon that we see in Theravada Buddhism.

The list of the five aggregates-including feeling, which gives rise to happiness and unhappiness-appears several times in Dogen's essays in the same form as in the Pali Canon, if we allow for variety in the translations of the Canon and Dogen. In "Reading a Sutra," for example, Dogen lists the five aggregates thus: "The realm of skandhas means the realm of five skandhas: form, perception, feeling, inclination, and discernment" ([19], p. 225). Significantly, the immediate context of this list is the need to be free from abiding in the skandhas. Dogen is recounting the words of Prajnatara to the King of East India, who has asked Prajnatara why he does not read sutras like everyone else. Prajnatara replies, "While exhaling I do not follow conditions. While inhaling, I do not abide in the realm of skandhas. I turn hundreds, thousands, myriads, and billions of scrolls of sutras, not merely one or two" ([19], pp. 224-225). To go beyond the five aggregates is to achieve the cessation of suffering that is the goal of Buddhist practice. It is consistently in the context of such practice that Dogen brings up the aggregates.

In another essay Dogen uses the titular term "dharma nature" to express practice beyond the aggregates: "All phenomena and dharma nature go beyond arguments about whether they are the same or different, about whether they are identical or separate. What is not past, present, and future, not permanent or impermanent, not form, perception, feeling, inclination, and discernment, is Buddha nature" ([19], p. 559). In "Arousing the Aspiration for Enlightenment," Dogen himself offers a source for his list of aggregates: the Indian philosopher Nagarjuna's Treatise on Realization of Great Wisdom ([19], pp. 663-663). Here, he describes the "demons of the five skandhas" as "causes and conditions of delusions interacting with one another" ([19], p. 662). These demons are distractions or obstacles to Buddhist practice. Thus, happiness itself, the source of which lies in the aggregate of feeling, actually hinders the cessation of suffering. Dogen's discussion of the aggregates includes happiness without explicitly naming it. In fact, a mention of happiness is a needle in Dogen's haystack; happiness is all but invisible there unless we understand its source in the five aggregates-which are listed explicitly in a number of Dogen's works-and attend to Dogen's focus on his alternative to the pursuit of happiness.

\subsection{Alternatives to Happiness}

For Dogen, the great alternative to the pursuit of happiness is Buddhist practice. In "On the Endeavor of the Way," for example, Dogen exhorts us to practice even though Zen empahsizes that every person already has Buddha nature and there is nothing to attain: "Although this inconceivable dharma is abundant in each person, it is not actualized without practice, and it is not experienced without realization" ([19], p. 3). Grasping at happiness-or deliberately avoiding unhappiness-will lead one to see such distinctions as happiness and unhappiness as something permanent, only to lead to eventual disappointment. Instead, Dogen advises us to "sit zazen [sitting meditation] wholeheartedly" with the fol- 
lowing point of view:

Know that fundamentally you do not lack unsurpassed enlightenment, and you are replete with it continuously. But you may not realize it, and may be in the habit of arousing discriminatory views, and regard them as real. Without noticing, you miss the great way, and your efforts will be fruitless. Such discriminatory views create flowers of emptiness. ([19], p. 10)

In his commentary on Dogen's essay "Actualizing the Fundamental Point" (Genjokōan), Hakuun Yasutani-roshi emphasizes the need to overcome the subjective consciousness or moods of happiness and unhappiness:

Only when you are in favorable circumstances and your good fortune goes along without a hitch do you seem to be somewhat at ease, but that's not the real thing. It's really only being drowned in favorable circumstances. How is it when you are assailed by repeated misfortune and continual misery? Can you really stand as firm as a rock and be completely at peace? ([20], p. 68)

This insistence on overcoming the vicissitudes of positive and negative experience is also Dogen's; in this essay, he calls it "leaping clear of abundance and lack" ([19], p. 29). As Nishiari Bokusan explains in his commentary on this essay, one's mind can be settled only "when body and mind are truly dropped off" ([21], p. 57). Such a "dropping off" necessarily includes the dropping off of happiness. Dogen's practice is expressed in more contemporary terms by Ajahn Chah:

If we really know the Dharma and see it continuously, nothing is anything at all; there are only arising and passing away. There's no real happiness or suffering. The heart is at peace then, when there is no happiness or suffering. [...] We are usually trying to stop suffering to give rise to happiness. That's what we want. But what we want is not real peace, it's happiness and suffering. [...] Doing good is supposed to bring good results, and if we get that, we' re happy. We think that's all we need to do, and we stop there. But can good experiences give us lasting satisfaction? It doesn't remain. We keep going back and forth, experiencing good and bad, trying day and night to seize on what we feel is good. ([22], pp. 62-63)

For both Dogen and Ajahn Chah, the goal of Buddhist practice lies in getting beyond, not merely to, happiness. This distinction is essential to an understanding of Buddhism, and it is an error to skew the goal of Buddhism toward happiness in order to support the radically different conception of the self that we see in the modern search for happiness. Indeed, since the absence of a lasting self is one of the core tenets of Buddhism, pursuing happiness for the sake of such a self is, from the Buddhist perspective, a grave mistake.

\subsection{The Literary Happiness of Dogen's Style}

Dogen's works nevertheless make clear that happiness itself-unlike the pursuit 
of happiness-is not something to be avoided. Purposely avoiding happiness would be no better than deliberately pursuing it, for in either case one would be controlled by circumstances. Like Ajahn Chah, Dogen does not teach or write his essays in order to cause happiness; yet through his activity, happiness is produced. To an appreciative reader, the literary style of Dogen's works tends to engender a type of literary happiness. Their balance, their startling metaphors, their charming fragments of narrative, and of course their instructiveness in Buddhist thought, all work to make the body of his work a masterpiece of poetic exposition. Below, I cite three passages as examples of the literary happiness of Dogen's works.

The first is from "Actualizing the Fundamental Point," an extended expression on the enlightenment experience. It is a triumphant overcoming of the proverbial difficulty expressing a realization that must be experienced by each person for him- or herself.

Enlightenment is like the moon reflected on the water. The moon does not get wet, nor is the water broken. Although its light is wide and great, the moon is reflected in a puddle an inch wide. The whole moon and the entire sky are reflected in dewdrops on the grass, or even in one drop of water. Enlightenment does not divide you, just as the moon does not break the water. You cannot hinder enlightenment, just as a drop of water does not crush the moon in the sky. The depth of the drop is the height of the moon. Each reflection, however long or short its duration, manifests the vastness of the dewdrop, and realizes the limitlessness of the moonlight in the sky. ([19], p. 31)

The precision and economy of this passage prevent the metaphor of moonlight from falling into the cloying banality of cliché. Like the Metaphysical poets of seventeenth-century England, Dogen returns to the same metaphor from different angles and manages to keep the essay fresh while doing so. The risk of repetition is great, but not a single sentence merely repeats anything we have already been told. The passage gives the impression of an infinite multiplicity of further extensions of the metaphor even as it exhausts them.

The next passage is from "The Time Being," an essay which, along with St. Augustine's discussion of time in his Confessions, must rank with the most penetrating examinations of time in literary history.

The way the self arrays itself is the form of the entire world. See each thing in this entire world as a moment of time.

Things do not hinder one another, just as moments do not hinder one another. The way-seeking mind arises in this moment. A way-seeking moment arises in this mind. It is the same with practice and with attaining the way.

Thus, the self setting itself out in array sees itself. This is the understanding that the self is time. ([19], p. 105)

The final sentence of this passage is perfectly anticipated by the first two, where the repeated phrase "entire world" serves to link the idea of self with the 
concept of time, without making that link explicit; the last sentence provides the closure of that explicitness. In between, the central paragraph conflates objects and time, then makes the mind an exemplary object only to show how objects are actually time, as the second sentence of the passage has already stated. The compression of concepts here is already impressive, but Dogen has not yet finished: the key point of the equivalence of practice and dharma, a point to which he returns again and again in his essays, is essential to the idea of the interpenetration of all things.

But dazzling metaphor, philosophical complexity, and density of exposition are not the whole story with Dogen. Like the twentieth-century American poet Wallace Stevens, who employed all of those elements of rhetoric and style, Dogen is capable of writing with disarming simplicity and directness. Here is a passage from "Continuous Practice, Part Two,"

Guishan, who would later become Zen Master Dayuan, went to the steep and Rocky Mount Gui immediately after receiving a confirmation of enlightenment from Baizhang. He mingled with birds and beasts, assembled a thatched hut, and tempered his practice. While living on acorns and chestnuts, he was not intimidated by storms or snow. Without temple or property, he actualized continuous practice for forty years. Later this place became a monastery renowned throughout China, where excellent practitioners like dragons and elephants came to follow in his footsteps. [...]

The sobbing rain of deep night pierces moss and pierces rock. On a snowy night of winter when even animals are rarely seen, how could the aromas from people's houses reach you? This kind of search is impossible without the continuous practice of taking your own life lightly and regarding dharma as precious. Without cutting grass or moving earth and lumber, Guishan was fully engaged in tempering practice of the way. ([19], pp. 369-370)

This simple narrative makes its didactic point with charm and directness. Writings like this one helped to establish a distinct Zen aesthetic that spread along with translations of the works of Dogen and subsequent writers who learned from him. Like Buddhist practice itself, such writing enacts happiness without addressing it explicitly. The absence of happiness as a topic is not the absence of happiness as an act of expression.

\section{The Place of Happiness}

To understand the writings of Dogen and other Buddhist authors, it is necessary to put them in the context of the Buddhist ideals and practices that aim for the recognition and elimination of suffering. Indeed, Soto Zen teachers have long used Dogen's texts as part of their teaching and practice. Even in a scholarly context, Kasulis has suggested that Dogen's texts be read as intimate encounters with Dogen himself, as "half of a dialogue, [...] a verbal presence to be taken up as soon as the reader is ready and willing to meet the person who wrote it" ([23], p. 91). In other words, reading Dogen requires a certain kind of effort on the part of the reader, an effort that perhaps surpasses the effort needed for literary 
texts that do not constitute part of a life-encompassing, intentional practice.

Dogen is nevertheless unavoidably literary. Even Zen teachers pick out Dogen's literary skill for particular praise. In his introduction to Dogen's koan collection, John Daido Loori, for example, writes, "Dōgen was a master of language. It is impossible to study his writings and not be moved by the poetry and creativity of his words" ([24], p. xxvii). Along with Dogen's "literary sophistication," however, Loori also notes his "extensive familiarity with Buddhism," "an unparalleled appreciation of he dharma," and an "ability to communicate on multiple levels" ([24], p. xxvii) as salient characteristics of his works. Indeed, the dharma of Buddhism provides both the goal and a large part of the means for Dogen's literary skill, a skill whose proper context lies within the practice of that dharma.

That context, like the writing it helps illuminate, loses a large part of its meaning when it is used to furnish philosophical support for ideas such as the modern pursuit of happiness, which are alien to it. Taken as a goal to pursue, happiness becomes just another matter of acquisitiveness, and thus is inimical to the goal of the elimination of suffering, of the achievement of a practice of equanimity beyond happiness or unhappiness, that is the true goal of Buddhism. Read with an understanding of that goal in mind, Dogen's works put happiness in its place: pursued, it is a hindrance; enacted in the practice of Buddhist dhar$\mathrm{ma}$, it is a joy.

\section{References}

[1] Davies, W. (2016) The Happiness Industry: How the Government and Big Business Sold Us Well-Being. Verso, London and New York.

[2] Watson, G. (2008) Beyond Happiness: Deepening the Dialogue between Buddhism, Psychotherapy and Mind Sciences. Karnac, London.

[3] Bhikkuhu Bodhi (1994) The Noble Eightfold Path: Way to the End of Suffering. PRS Paryatti, Onalaska.

[4] Ajahn Chah (2002) Food for the Heart: The Collected Teachings of Ajahn Chah. Wisdom, Boston.

[5] Roscoe, G. (1994) The Triple Gem: An Introduction to Buddhism. Silkworm, Chiang Mai.

[6] Tran, C.T. (2004) The Buddha and the Way to Happiness. Infinity, West Conshohacken.

[7] Bien, T. (2010) The Buddha's Way of Happiness: Healing Sorrow, Transforming Negative Emotion \& Finding Well-Being in the Present Moment. New Harbinger, Oakland.

[8] Ajahn Chah (2001) Being Dharma: The Essence of the Buddha's Teaching. Breiter, P., Trans. Shambala, Boston and London.

[9] Achaan Chah (1985) A Still Forest Pool: The Insight Meditation of Achaan Chah. Compiled by Kornfeld, J. and Brieter, P. Quest, Wheaton and Chennai.

[10] Dalai Lama and Cutler, H.C. (2009) The Art of Happiness: A Handbook for Living. Riverhead, New York.

[11] Breiter, P. (2004) Venerable Father: A Life with Ajahn Chah. Paraview, New York. 
[12] Kapleau, P. (2000) The Three Pillars of Zen: Teaching, Practice, Enlightenment. Anchor, New York.

[13] Fox, A. (2013) The Huayan Metaphysics of Totality. In: Emmanuel, S.M., Ed., $A$ Companion to Buddhist Philosophy, Wiley-Blackwell, Chichester. https://doi.org/10.1002/9781118324004.ch11

[14] (2000) The Connected Discourses of the Buddha: A Translation of the Samyutta Níkāya. Bhikkhu Bodhi, Trans., Wisdom, Somerville.

[15] (1995) The Long Discourses of the Buddha: A Translation of the Dīgha Níkāya. Walshe, M., Trans., Wisdom, Somerville.

[16] Ācariya Anuruddha (2000) A Comprehensive Manual of Abhidhamma: The Adhidhammattha Sangaha of Ācariya Anuruddha. Bhikkhu Bodhi, Ed., Mahaāthera Nārada and Bhikku Bodhi, Trans., Introductory and Explanatory Guide by U Rewata Dhamma and Bhikkhu Bodhi, BPS Pariyatti, Onalaska.

[17] Venerable Nyanaponika Thera (2015) Abhidhamma Studies: Buddhist Explorations of Consciousness and Time. BhikkhuBhodi, Ed., Wisdom, Somerville.

[18] LaFleur, W.R. (1985) Dōgen in the Academy. In: LaFleur, W., Ed., Dōgen Studies, Studies in East Asian Buddhism, No. 2, University of Hawaii Press, Honolulu, 1-20.

[19] Dogen (2012) Treasury of the True Dharma Eye: Zen Master Dogen's Shobo Genzo. Tanahashi, K., Trans., Shambala, Boston and London.

[20] Yasutani, H. (1996) Flowers Fall: A Commentary on Zen Master Dōgen's Genjokoan. Jaffe, P., Trans., Shambala, Boston and London.

[21] Weitsman, M., Wenger, M. and Okamura, S. (2011) Dogen's GenjoKoan: Three Commentaries. Counterpoint, Berkeley.

[22] Ajahn Chah (2005) Everything Arises, Everything Falls Away: Teachings on Impermanence and the End of Suffering. Breiter, P., Trans., Shambala, Boulder.

[23] Kasulis, T.P. (1985) The Incomparable Philosopher: Dōgen on How to Read the Shōbōgenzō. In: LaFleur, W., Ed., Dōgen Studies, Studies in East Asian Buddhism, No. 2., University of Hawaii Press, Honolulu, 83-98.

[24] Loori, J.D. (2009) The True Dharma Eye: Zen Master Dōgen's Three Hundred Kōans. Tanahaski, K. and Loori, J.D., Trans., Shambala, Boston and London. 